\title{
Forkhead Box Protein G1
}

National Cancer Institute

\section{Source}

National Cancer Institute. Forkhead Box Protein G1. NCI Thesaurus. Code C17584.

Forkhead box protein G1 (489 aa, $\sim 52 \mathrm{kDa}$ ) is encoded by the human FOXG1 gene. This protein is involved in transcriptional regulation, and brain development. 